\title{
The Implementation of Song and Motion Learning Through the Model of Beyond Center Circles Time (BCCT) to Improve Early Childhood Creativity
}

\author{
Retno Tri Wulandari \\ Early Childhood Education Departemen \\ State University of Malang \\ Malang, Indonesia \\ Corresponding e-mail: retno_um@yahoo.co.id
}

\begin{abstract}
The purpose of this study is to describe the implementation of song and motion learning as well as to increase early childhood creativity through the model of Beyond Center Circles Time (BCCT). The research method that is used was a classroomaction research with a collaborative model while the subject was Tunas Harapan Kindergarten (group B) in Srengat, Blitar with 15 children in the academic year 2015/2016. The data collection techniques were carried out in observation, interview, performance appraisal, and documentation. Furthermore, the indicators of creativity were fluency, flexibility, originally, elaboration, and sensitivity. The results showed that the level of children's creativity on children's preaction percentage of growing as expected could reach $32,75 \%$. In cycle I, the result has reached $51,33 \%$ while in cycle II the percentage has reached $89,6 \%$. The total percentage of children's creativity improvement that occurs from pre-action to cycle II resulted in $56,9 \%$ of the total 15 children. Thus, it can be said that there is an increase in the creativity. The conclusion of this research is that the implementation of song and motion learning through BCCT model could improve the creativity of early childhood.
\end{abstract}

Keywords: $\quad$ song and motion learning, BCCT model, early childhood creativity.

\section{INTRODUCTION}

The implementation of early childhood education is intended to provide a variety of basic skills in children. Basic skills are required to develop attitudes, knowledge, skills, and creativity which are necessary for an effort to the environment adaptation and for further development. With regard to the achievement of basic skills, song and motion learning is one of the programs that must be developed because the process of early childhood learning, in fact, is never separated from the activity of moving and singing. Another consideration that is used as a basis for the implementation of song and motion learning is the need for early childhood to express aesthetically and creatively through the field of art. The art of dance is a field of art development that is included in the school curriculum because of the uniqueness, significance, and usefulness for children's development. This lies in the aesthetic experience in the form of expressing, creating, and appreciating art through the approach of "Learning with art, learning through art, and learning about art".

Early childhood education can organize art development in accordance with the teacher's ability. Teachers are given freedom in developing the learning materials. Broadly speaking, art development activities cover 2 aspects which are appreciation and expression. For an instance, dance for early childhood education is in the form of motion and song, dance play, and rhythmic gymnastics [1]. Song and motion learning in this study was chosen as one of the forms of art learning that are used to develop children's creativity. Things that must be understood in the learning of motion and song is that art, not just an imitation but art as children's expression.

A special value called creativity is required in the process of song and motion learning. Creativity can be interpreted as the ability to find new solutions to a problem. This value will encourage the development of all potentials in children's early childhood. In accordance with the opinion of creativity [2] needs to be nurtured at an early age because an individual can realize his/her true self with creativity. Creative thinking is seen as a capability to see various possibilities of solving a problem. Unfortunately, this aspect still received less attention in education until now. Engage ourselves with creativity not only delivers good impact for the personal and the environment but also gives satisfaction to the individual. Creativity allows humans to improve their quality of life individually as well as the whole human race. Creative Behavioral indicators include: (a) fluency, (b) flexibility, (c) elaboration, (d) originality, and (e) sensitivity. In details, fluency is the ability to 
express similar ideas to solve a problem; flexibility is the ability to produce a wide range of ideas to solve a problem outside the category; elaboration is the ability to express ideas briefly in detail to realize the ideas into reality; originality is the ability to provide a unique or extraordinary response; lastly, sensitivity is the sensitivity to capture and generate problems as a response to a situation [3].

The learning activity of motion and song is carried out by children in the form of dancing that is adapted to the poetry and rhythm of the song. This activity is expected to train sensitivity towards motor development, confidence, courage, and creativity enhancement. Generally, song and motion learning for early childhood is conducted by using a model/approach of drill or demonstration which is by imitating teacher movement. However, this could cause a boredom for children so that it needs to be tested by using another learning model, one of which is by Beyond Center and Circles Time (BCCT) model. BCCT model is a "learning model center" which is performed in a circle (circle time). In other words, this is an approach to early childhood education developed by Creative Center for Childhood Research and Training in the United States. BCCT model in its application can be implemented gradually and can be modified according to the existing learning situation and condition of the school.

Based on previous studies, the results of preliminary observations and interviews with the school principal indicate that the problems of art learning occurred in Tunas Harapan Kindergarten, Srengat are: a) teachers who do not have the background of dance causes the lack of knowledge to plan the song and motion learning, b) the lack of teachers' creativity in applying the right model for song and motion learning resulted in less motivated children to imitate the movement and a difficulty to memorize the movement and to adjust the song, c) song and motion learning is more focused on the final semester activities (race events, farewell party, or final art performance), d) $60 \%$ of the total 15 children feel less confident when the teacher asks to move according to the rhythm of motion and song, e) the lack of children's learning tools and media such as interactive CD, DVD, or even computers, f) the fact that each child has different interest of arts and different levels of motor skills.

Based on the problems above, an effective learning model in song and motion learning activities is essentially needed. The advantages of song and motion learning are that children can have free expressions, channel their ideas, control and create feelings of pleasure and agile. This is closely related to the psychomotor development of the child itself. The required learning model is expected to provide opportunities for the growth of children's creativity and courage as well as to accommodate their individual differences. By that, the learning model proposed by the researcher is BCCT model. The advantage of BCCT is that this model is more entertaining thus it can be a vehicle for active and creative thinking. This is in contrast with the drill model which more on imitation and memorizing. Researchers hope that BCCT model could enhance children's creativity.

The issue of early childhood creativity improvement in song and motion learning need to be immediately solved. In this study, the most appropriate action is to implement an appropriate learning model for early childhood learning that is adjusted with the problems in the field. Based on the description of the problems, the researchers are interested in examining the implementation of song and motion learning through BCCT model (Beyond Center and Circles Time) to enhance children's creativity at anearly age.

\section{RESEARCH METHODS}

\subsection{Types of Research}

The study used a qualitative approach with the design of classroom action research.PTK dilakukan secara bertahap dan bersiklus, untuk mengetahui peningkatan kemampuan seluruh peserta didik dalam 1 kelas. Classroom action research was conducted in stages and cycles to determine the ability improvement of all learners in the class. This was also done collaboratively where teachers practice the teaching process and researchers act as anobserver. Classroom action research that was used in this case was in accordance with model [4]. The subjects of the study were the children of group $B$ in Tunas Harapan Kindergarten, Srengat Subregency, Blitar with a total of 15 children consisting of 5 boys and 10 girls at the age range of 5-6 years old. The study was conducted in the academic year of 2015/2016. Meanwhile, the data collection techniques used were observation, interview, performance appraisal, and documentation and the research instruments were observation sheets, interview guides, performance appraisals, and photo document of the learning process. The observations were made to collect data on children's activities, learning processes, and motion and song implementation through BCCT model. The interviews were conducted to explore the problems, the process, the obstacles, and the impact of the action that occurred in the classroom. Performance appraisal in here was done at the end of the learning process to evaluate the improvement of children's creativity. The data were obtained by using qualitative and quantitative data analysis techniques. Furthermore, the success criteria in the mastery of the material are the indicators of creativity improvement such as fluency, flexibility, originally, elaboration, and sensitivity. 


\section{RESULT}

\subsection{Pre-action Data Exposure}

Based on observations on Tunas Harapan Kindergarten, the learning process was conducted by using classical learning model because they considered that it is easier in terms of material provision. This will make children to have limited creativity and only follow teachers' instructions. In the initial condition, the improvement of children's creativity is still low. This can be seen in the learning situation that the children tend to play on their own rather than following the rules of the game, they also have low enthusiasm when the teachers invite them to play a game that is focused on the creativity development. Moreover, children seem unable to create the desired work because there is no courage in producing the work, they are dominated by fear (low self-esteem) and also the lack of motivation in making good motor activities such as dancing from the teachers. Particularly, dancing is still less explored in school so that children are less motivated to move.

Based on the interviews with theschool principal, up to now, this dance activity is less done by the teacher because the teachers do not have enough background to develop physical materials in the form of art activities, especially dance. This activity only appears at the end of the semester only at agraduation ceremony or race events. Until now, the classical learning model cause the dancing activities to be performed in the form of drill learning model by imitating the movement of the teachers directly so that this makes children's creativity tends to be low. This also makes the children's enthusiasm to be reduced due to the emerging saturation or boredom. Therefore, new learning models and materials that can motivate the emergence of early childhood creativity are required.

Table 1. Datum Observation Research from Creativity Pre-Action

\begin{tabular}{ccccc}
\hline Indicator & Sum & Average & $\%$ & $\begin{array}{c}\text { Grade } \\
\text { completesness }\end{array}$ \\
\hline Fluency & 38 & 1,9 & $47,5 \%$ & $20 \%$ \\
Flexibility & 32 & 1,6 & $40 \%$ & $25 \%$ \\
Originality & 28 & 1,4 & $35 \%$ & $0 \%$ \\
Elaboration & 0 & 0 & $0 \%$ & $0 \%$ \\
Sensitivity & 33 & 1,65 & $41,25 \%$ & $10 \%$ \\
\hline
\end{tabular}

In general, the data of children's creativity in children pre-action learning are still lacking within the indicators of fluency, flexibility, originality, elaboration, and sensitivity with an average of $32,75 \%$ creative abilities. This means that almost
$70 \%$ of children have not developed their creativity skills. It is formed by the classical methods used by teachers in the learning process so that children tend to be passive and less motivated to issue their ideas or just obey orders from the teacher. Unfortunately, no one even took the initiative to solve the problems faced in the learning process. Based on the data exposure, the researchers then have implemented a follow-up action to cycle I.

\subsubsection{Cycle I Data Exposure}

Quantitatively, the results of the cycle I can be described that the improvement of children's abilities in each indicator of creativity has begun to increase. In the first cycle, in terms of the improvement of children's abilities, there are 2 undeveloped children while there are 5 children who begin to grow. On the other hand, the children who grow as expected are as many as 8 children. In this cycle, I, thecreativity of children has begun to develop but there is only 1 indicator that the percentage of children maximum growth is exceeding $50 \%$. After the assessment data is analyzed, the teacher reflects on the learning activities that have been implemented. At this stage, the researchers and the teachers try to know the ability of the children in the learning process which previously has been done in cycle I. The results of this first observation were used to determine the action in the next cycle.

From the results of learning activity and ability obtained in cycle I, we can see some weaknesses in this study such as (1) children do not enjoy the process in every activity, (2) the material has not been clearly communicated, (3) children still need teachers' guidance in doing song and motion learning. The reasons behind those weaknesses are the poor class conditioning, poor use of time allocation in object exploration before children perform their motion expressions, and a lack of affirmation in game rules. The score of the children who have reached the development was $51,33 \%$, therefore the study will continue in cycle II.These are some improvements to cycle I that are planned to be improved in cycle II: (1) provide examples until the children fully understand all the activities in the learning center; (2) class conditioning is further enhanced by group division; (3) invite children to watch videos that fit the theme, as for an instance, a goose story delivered in a short time and more interesting way; (4) in order to not become boring, teachers invite children to do games when it comes to differentiating the size of the goose; (5) always give rewards at the end of the activities.

\subsubsection{Cycle II Data Exposure}

In cycle II, it can be seen that from 5 indicators of creativity, 4 indicators have reached 
more than $50 \%$ and the level of child development in all indicators is already above $60 \%$. However, it is found that 1 indicator still at the level of underdeveloped by $29,3 \%$ which is idea-expression based on theme and game. Overall, the achievement of children's creativity in cycle II showed an increase compared to cycle I. The percentage of children who achieved the ability of creativity in cycle I have reached $51,33 \%$ while in cycle II it has reached $89,6 \%$. The increase that occurred in cycle I to cycle II is $38,3 \%$. This has fulfilled the standard of children's creativity improvement in Tunas Harapan Kindergarten, which is at least $75 \%$ of the total children.

From learning activity in cycle II, it results in some findings that are: (1) children's activities in motion and song game are already above the specified minimum standard; (2) the learning implementation to improve children's creativity through motion and song game can be done better than cycle I. All indicators and learning objectives have been achieved in cycle II; (3) children's creativity is increasing; (4) there are children who have not developed well in the learning activities due to their low confidence level; (5) The children who could reach a good development level and in accordance with the expectation are $89,6 \%$. This actually has met and exceeded the minimum standards so that this research is considered to have worked well.

\subsubsection{Research Findings}

The learning quality has increased from cycle I to cycle II. The actions of the teachers in the learning process provide an interesting and memorable thing for children. It can be seen that in Cycle I: (1) most children have not been able to speak up with confidence; (2) they have not been able to solve the problems in games that match the theme. While in cycle II, children have succeeded in realizing the song and motion learning and in reaching the development of the specified creativity indicators. The results of the research can be seen in Table 2 below:

Table 2. The Results of Child Creativity Capability Improvement Start from Pre-action, Cycle I, and Cycle II

\begin{tabular}{cccc}
\hline $\begin{array}{c}\text { Number } \\
\text { Pre-Action }\end{array}$ & Cycle I & Cycle II & Improvement \\
\hline $32,75 \%$ & $51,33 \%$ & $89,6 \%$ & $56,9 \%$ \\
\hline
\end{tabular}

Based on the data in Table 2, it appears that the level of children's creativity on the pre-action has reached $32,75 \%$. The increase that occurred in pre-action to cycle I am $18,58 \%$. In cycle I, the percentage of well-developed children has reached $51,33 \%$, means that the increase occurred in cycle I to cycle II is $38,3 \%$. Different result happens in cycle II which this has reached $89,6 \%$ and the total increase that occurred from pre-action until cycle II is $56,9 \%$ of the total of 15 children

\section{DISCUSSION}

\subsection{The Implementation of Song and motion learning through BCCT Model}

Song and motion learning has a huge contribution to children's creativity because it can train children to be more spontaneous and creative in conveying ideas. Children activities in song and motion can develop children's imagination and motivate children to be bravely express feelings or ideas as expressed by [1] that motion and song is an example of game materials tailored to the ability of children motor development. Motion is created as an expression of the song so that motion is made in the half of the overall proportion of the display and song is also displayed with the correct vocal technique as half of the overall proportion. So, the movement of motion does not prioritize the aesthetics value because it must be in accordance with the song lyrics as a meaning of the song. Otherwise, the song should also be trained in the correct tone, rhythm, and dynamics techniques although it should not be so strong that the children almost do not move.

The song and motion learning through BCCT model are applied by the way the teacher prepares the equipment to be used and prepares several choices of activities in the art center used that day that is in accordance with BCCT model theory. This model is a fun learning model for the children as it is in correlation with children's initiative and build experiences in spite of only imitating [5]. In the learning implementation, children can choose the activities prepared by teachers based on their respective interests. Teachers encourage children to sit in a circle (circle time) to begin the study. The learning process uses four footholds that are the structuring of the tools, footholds before play, footholds during play, and footholds after play. The children perform various game activities according to the theme before playing the game with motion and song material. The activity will come to an end when the teachers ask the children to retell their experiences in the art center that day. Children who are brave to tell their experiences will be rewarded by the teachers so that children are motivated to express thoughts.

The implementation of song and motion learning is under the consideration that the steps are arranged in a systematic way so that the results will be more leverage. In accordance with the opinion of Wulandari [6], the stages in the learning process of motion and song or dancing in early childhood 
are described as follows: (1) adjusting children's psychological condition and then choosing the theme of the song motion (2) choosing a natural theme or a theme that is close to the children's life, (3) selecting a low difficulty movement so that children will be able to follow, (4) choosing a moderate, soft, and fast dynamic path because dynamic variations will train various forms of child emotion. (6) making the motion pattern as simple as possible, (8) teacher should master the song and motion before it is given to the children, (9) the movements are given gradually, begins with one kind of movement, because one motion requires a motor coordination that takes thetime to be trained. (10) making the interlude in the form of a story that is relevant to the theme of the song/dance, (11) if all of the motions have been reached, it is necessary to be repeated so that the dance becomes optimal, (12) early childhood educators must be good at sharing the song and motion material in several meetings, things that need to be concerned are the physical and psychological condition of the children. In principle, do not force the children if the condition is not possible anymore.

Based on the above description, it can be concluded that the implementation of song and motion learning performed by the teachers does not directly give examples to be only imitated by the children but they are stimulated to express the idea of the motions based on their own creativity. Thus, the creativity of children will be trained for further development.

In cycle 1 , children tend to be enthusiastic to follow the game, they start to express their ideas or answer questions smoothly, they also flexible in producing a wide range of ideas based on the subthemes, they have unique respond toward the game in the aspect of originality, and they begin to follow the rules in each foothold game. However, in the aspects of detail or problem solving, the conditions are still the same as the initial conditions because children have not been able to create their own problem-solving in various types of games neither realize the idea in real terms.

The activity of song and motion learning in cycle II has resulted in the children who express ideas in the game smoothly, they do all aspects very well, they are flexible in generating ideas based on the sub-themes, they began to show their unique responses and started to solve the problem in various types of games. This is in line with the opinion of [6] that children's psychomotor skills emphasize the awareness creation to move spontaneously, they are demanded to move smoothly, orderly, flexible, and expressive without any burden in doing the motion and singing the song.

\subsection{Improving Early Childhood Creativity Through the Implementation of Song and motion learning with BCCT Model}

After the two cycles of classroom action research of early childhood in Tunas Harapan Kindergarten, Srengat Sub-district, Blitar, the results showed that the implementation of song and motion learning through BCCT model can improve the creativity of early childhood. This is in accordance with the opinion of that in song and motion learning, the creativity competencies contain the aspects of cognitive, affective, and psychomotor that is seen in the product or the work and in the process of creative activity [6].

Song and motion learning can also provide a fun experience as well as cultivate confidence and develop children's creativity. Creativity comes with spontaneity without the coercion of others, creativity arises through self-created movements [7]. The early creative ability of early childhood can be recognized by the ability to create unique movements, like the ability to make new moves and the speed to adjust to other friends when they make mistakes in the dance. So, in the song and motion learning for early childhood, teachers play a role to direct the children and provide stimulation and motivation for them to move.

The increased creativity can be seen from several indicators that are in the process of song and motion learning improvement through BCCT model. Based on the opinion of [3], creative ability can be generated through problems that spur the following five creative behaviors (a) fluency, (b) flexibility, (c) elaboration, (d) originality, and (e) sensitivity. Fluency is the ability to express similar ideas to solve a problem. Flexibility is the ability to produce a wide range of ideas to solve a problem outside the category. Elaboration is the ability to express ideas briefly in detail to realize the ideas into reality. Originalityis the ability to provide a unique or extraordinary response. Lastly, sensitivity is the sensitivity to capture and generate problems as a response to a situation.

The efforts to improve children's creativity in song and motion learning of early childhood through the model of Beyond Centers and Circles Time (BCCT) are described as follows, there is one aspect that has not been developed which is elaboration at the initial conditions before using the BCCT model.Children have not been able to create their own problem solving of various types of games and have not been able to realize the idea in real terms. This is supported with the idea of Piaget that early childhood from the age of 2-4 years old is colored by imagination. In general, they are still difficult to distinguish between imagination and reality. The complicated processes that occur in a computer are as complex as those in the human brain. Like computers, human brain also receives information, processes it, and then answers. Similarly, early childhood is not able to receive, process, and realize full information in atangible form so that teachers need to be direct and guide the children as expected.

Based on the results of the study, there is an increase in the indicator of flexibility that it increasingly becomes more prominent. According to Vygotsky, the highest cognitive process that develops when children are 
in school is the interaction time between children and teachers. The knowledge gained from a particular cultural environment will be part of their knowledge. This can be seen from the ability of children to performflexible movements and perform activities in accordance with the instruction of the teachers.

In cycle II, all indicators begin to increase. The fourth indicator has begun to show an increase even though it only appears in 2 students. From the observation, two of these learners have a level of good understanding in ideas according to what is thought and able to realize it in the form of thereal game but it still needs guidance from the teacher. To stimulate the indicators, teachers provide BCCT model in every learning cycle. Creativity in early childhood can be enhanced through the implementation of song and motion learning with BCCT model. In line with the theory of neuroscience, BCCT model in children will create a rich experience of a supportive environment, as for an example, teacher may provide the tools to play, give enough playing time, and conduct activities which allow children to move freely in order to develop the ability, of one of which is dancing [5].

\section{CONCLUSION}

The conclusions of this study are (1) song and motion learning implementation through BCCT model by preparing all game equipment and multiple choices of activities in the art center that day. Teachers then invite children to sit in a circle (circle time) to begin studying. In this case, the learning process is carried out by using 4 footholds that are foothold structuring, foothold before play, foothold during play, and foothold after play. Children are expected to do all kinds of activities in accordance with the theme of the game with motion and song material, (2) BCCT model implementation in song and motion learning is seen to improve the creativity of children at an early age.

The suggestion drawn in this research is that it is expected to obtain maximum results in the form of follow-up plans, such as (1) Tunas Harapan Kindergarten, Srengat Sub-district, Blitar could provide support in the form of educational games to facilitate the creativity improvement through BCCT model so that teaching and learning in the classroom can be done well, (2) in order to get maximum results in children's creativity improvement, it is required to select the themes, motion materials, and children's songs in accordance with the environment of early childhood.

\section{REFERENCES}

[1] Setyawati, Sri. (2012). Pendidikan Seni Tari dan Koreografi untuk anak usia dini (Edisi Revisi). Surabaya: Unesa University Press.

[2] Munandar, Utami. (2012). Pengembangan Kreativitas Anak Berbakat. Jakarta: Rineka Cipta.

[3] Nursisto, (1999). Kiat Menggali Kreativitas. Yogyakarta: Mitra Gama Widya.

[4] Kemmis and Taggart. (1990). The actioan Research Planner. Victoria. Deakin. Univ Press.

[5] Departemen Pendidikan Nasional. (2006). Pedoman Penerapan Pendekatan Beyond Centers And Circles Time (BCCT) (Pendekatan Sentra dan Saat Lingkaran) Dalam Pendidikan Anak Usia Dini. Jakarta: Departemen Pendidikan Nasional.

[6] Wulandari, Retno Tri. (2014). Pembelajaran Olah Gerak dan Tari sebagai Sarana Ekspresi dan Apresiasi Seni Bagi Anak Usia Dini. Artikel Proseding

[7] Rachmawati, Yeni dan Euis Kurniati. (2010). Strategi Pengembangan Kreativitas Pada Anak Usia Taman Kanak-Kanak. Jakarta: Kencana Prenada Media Group. 